\title{
Types, Forms and Major Product Categories of Product Placement in the Czech Republic
}

\author{
Jan Kramolis and Martina Drabkova \\ Tomas Bata University in Zlin, Faculty of Management and Economics, Zlin, Czech Republic
}

\begin{abstract}
Product placement is defined as marketing integration of a product or a brand into a film or televised series in order to avoid conventional advertising. In this paper, there are different categories of products which are promoted by means of product placement. The main objective of product placement is to connect brands with the appropriate entertainment partners to maximize exposure and brand relevance. Product placement can occur in audio-visual works in several different forms. And finally, the last question in this paper is about describing product categories promotion by Product placement. According to the primary survey, the several groups of product categories (automotive industry and mobile phones and computers) are mostly promoted by product placement.
\end{abstract}

Keywords: Product placement, types and forms of product placement, products category, Czech Republic.

\section{Introduction}

Marketing communication represents all relevant communication with the market. According to Vysekalová and Mikeš (2010), "traditional" forms of communication such as advertising, sales promotion, public relations, direct marketing and sponsoring can all be classed as marketing communications". However, a series of changes has been made to these traditional forms due to new specialized branches, techniques and media that have emerged and which need to employ marketing tools even more.

The results of the study by Chen and Leu (2011), show that scepticism toward advertising had a negative effect on brand attitude and purchase intention. Product involvement had a positive effect on brand attitude and purchase intention. However, scepticism toward advertising did not have a significant effect on brand attitude and purchasing intention when the interaction effect of scepticism toward advertising and product involvement were considered. The interaction effects might dilute the negative influence of consumers' scepticism toward advertising on brand attitude and purchasing intention.

Lexus (2010) mentioned that advertising is commonly carried out in a manner that is direct and persuasive, but this is not the case with embedded marketing or product placement. Unlike traditional television and radio advertising which sends a direct message about a product or service, embedded marketing subtly exposes the audience to the same without the use of ads.

On the basis of the research carried out by Shopper Watch (2011), it can be stated that while consumers are reluctant to acknowledge the effect of advertising, it is interesting to note that almost one in five

Copyright (C) 2012 Jan Kramolis and Martina Drabkova. This is an open access article distributed under the Creative Commons Attribution License unported 3.0, which permits unrestricted use, distribution, and reproduction in any medium, provided that original work is properly cited. Contact author: Jan Kramolis Email: kramolis@fame.utb.cz 
under 35s admit that they would consider buying a product endorsed on a TV programme or film.

Hudson and Hudson (2006) mentioned that definitions of product placement have changed over the years. An early definition is the one by Balasubramanian who defines it as the planned entries of products into movies of television shows that may influence viewers' product beliefs and/or behaviours favourably.

Powell et al (2009) referred to the US Federal Trade Commission defining product placement as a form of promotion in which advertisers insert branded products into programming in exchange for fees or other consideration.

Associate Marketing Professor at Panthéon Sorbonne University, Jean-Marc Lehu (2007) states that the expression "product placement" or "brand placement", essentially describes the location or, more accurately, the integration of a product or a brand into a film or televised series. It is also possible to find commercial insertions within other cultural vehicles, such as songs or novels.

Czech authors Přikrylová and Jahodová (2010) define product placement as the use of a real branded product or service usually directly in the audio-visual works (films, TV programmes and series, computer games), in live broadcasting and shows or in books which are not promotional in nature, under clear, contractually agreed conditions. For that reason, it is not considered to be hidden advertising, but rather a certain analogy to commercial communications or an advertorial and, therefore, an alternative way of placing an advertisement for a product or a brand.

Another definition of product placement can be found in a Czech book by Vysekalová and Mikeš (2010). They describe product placement as a deliberate and paid placement of a branded product into audiovisual works with the aim of its promotion.
This is essentially based on working certain contractor's products or services in a film, serial, musical or other plots.

Kureshi and Sood (2010) note that the work in product placements began in 1996 (1.69 $\%$ ). It gathered momentum only in 2004 $(10.17 \%)$ and attained its peak a decade later in 2006 (28.81\%).

The different authors show that product placement could be found in various audiovisual works. It is probably the most frequent in films (e.g. James Bond); Lehu (2007) also mentions the use of product placement in series and television programmes (Friends, American Idol), novels and plays (The Da Vinci Code), song lyrics (Humble neighbourhoods by Pink) or branded videogames (FIFA 06, London Taxi). Nevertheless, in the present article the researchers will focus exclusively on the onscreen product placement, that is product placement in films, TV programmes and series.

Pálková (2010) referred to the fact that product placement can be used either in a dominant or non-dominant shot. In the dominant shot, there is a direct shot at a certain product, occupying a significant part of a television screen. In this way, the product is immediately identifiable by a viewer. However, when there is an indirect shot at a product in the background and the product itself occupies a minor part of the screen, we speak about a non dominant shot. In the latter case, the product is merely a natural part of the shot that does not disturb. At the same time, the viewer's perception of the product is not a condition.

In the book by Přikrylová and Jahodová (2010), product placement can occur in audio-visual works in three different forms:

1. The product is openly discussed in the works (there is a verbal reference).

2. The product is being used by one of the characters in the works (active placement). 
3. The product is captured in a shot in a film or a television show or placed in a virtual environment (passive placement).

Lehu (2007) means by the verbal reference that we understand not only the pronouncing of the brand name, the producer's name or the service, but also the pronouncing of basic characteristics by which the brand, the producer or the service is identified. In a research study by Balfanz et al (2001), extended information availability in combination with the eye-catching effect of video presentations as well as the fun using interactivity, reaches the goal to attract the customer attention.

Lehu (2007) considers product placement from a different point of view. He distinguishes four types of product placement, namely classic placement, corporate placement, evocative placement and stealth placement, each of them bearing its potential benefits and disadvantages.

- Classic placement has existed since the technique was first originated. It is much more tactical than strategic, since it is a matter of making a product or a brand appeal in the camera's view.

- Principal potential benefit: the classic placement is fairly simple and easy to put in place, at a relatively low cost.

- Possible disadvantage: it may easily pass unnoticed, especially if there are a high number of placements in the same film.

- Corporate placement prioritizes the brand over the product.

- Principal potential benefit: institutional placement is often easier to exploit onscreen, including after filming, and it ages less rapidly.

- Possible disadvantage: it may easily go unnoticed, since it assumes that viewers know the brand name before watching the film.
- In the case of evocative placement, the operation is more discreet, in the sense that the brand does not appear, nor is it clearly cited onscreen.

- Principal potential benefit: the evocative placement is subtler than the classic placement and de facto suggests a real differentiation between it and its competitors.

- Possible disadvantage: it might not be identified by the audience unfamiliar with the brand.

- Stealth placement is highly discreet, almost undetectable. Often well integrated into the scene, its unobtrusive presence owes it a natural aspect, which may generate a more powerful impact and force of conviction when it is identified.

- Principal potential benefit: the stealth placement is generally perfectly integrated into the story or the scene in which it appeals, and thereby avoids criticisms of commercial overtones.

- Possible disadvantage: it can easily pass completely unnoticed.

Williams et al (2011) mentioned that there are several downsides of using product placement: lack of control, media programming may not be successful, possibility of negative character association, difficulty in pricing product placements and product placement ethics. In this article the researchers will concentrate on the question of ethics.

Many consumers and researchers consider product placement as an excessive commercialization of the media and an intrusion into the life of a viewer. The viewer does not go to the movie or television to see the product placement. The viewers often rather attend the movies and television to escape the realities of life. As such, marketers must make the product placement look obvious at the point of emergence. If the plot 
connection and the reflection of the user or character in the film are missing, the product placement is often futile. Consequently, the relevance of the product to the situation needs to be created by possibly incorporating placement planning at the script level. Product placement caters to a captive audience, even though the brands are shown in their natural environment.

In spite of that fact, in the research study by Williams et al (2011), some individuals feel that product placement is dangerous and should be banned or at least clearly disclosed in the credits at the end of the program. This is particularly true for an implicit product placement that should be avoided since they are perceived as less ethical than the other types of product placements, particularly if they appear in an information/series of a television program. Similarly, consumers' ethical opinions of product placement differ significantly across product categories, with greater concern for ethically controversial products such as alcohol, cigarettes and guns. The research by Hudson and Hudson (2006) has confirmed that consumers are concerned about the "subliminal" effect of brand placement. Other fear that brand placement's influence on the content of movies and television, is seen by many as inviolate. Ethical issues related to product placement and branded entertainment also warrant further investigation. The perception on the ethics of product placement can be also influenced by a gender division of society.

Table 1: Positive and Negative Features of Ethic (Zebrowski and MacDonald, 2007)

\begin{tabular}{|c|c|}
\hline Positive features & Negative features \\
\hline $\begin{array}{l}\text { - It is ethical if the products being placed } \\
\text { are appropriate in the context of the } \\
\text { program. } \\
\text { - It is ethical because the products are real, } \\
\text { and the program takes place in reality. } \\
\text { - It is ethical because the viewers benefit } \\
\text { from the product they learn about, and } \\
\text { the content paid for. } \\
\text { - It is ethical, because advertisers are } \\
\text { teaching us things all the time, even when } \\
\text { we were children. }\end{array}$ & $\begin{array}{l}\text { - It is not ethical, if the product is being } \\
\text { forced upon the viewers without regard } \\
\text { for context. } \\
\text { - It is not ethical because it sheds false } \\
\text { light on products. } \\
\text { - It is not ethical because no one ever } \\
\text { asked you for your permission. } \\
\text { - It is not ethical because we may learn } \\
\text { incorrect information that skews our } \\
\text { ideas. }\end{array}$ \\
\hline
\end{tabular}

Zebrowski and MacDonald (2007) posit that teleological theory says that it is ethical because the masses benefit from entertaining content and learn about new product.

According to Guido et al (2010), the research highlights product placement acceptability on gender basis, especially for some products. The results show a statistically significant difference for two of the ethically charged products: "alcohol" and "guns" in movies are more accepted by men. "Cigarettes" have lower results in gender differences but follow the trend of "alcohol" and "weapons". Among the neutral items, only one statistically significant difference is identified: "healthy products" is more accepted by women.

In the research study by Williams et al (2011), it is mentioned that however, it should be pointed out that while social critics and consumer interest groups may lean toward government intervention of product placements, audience is generally accepting product placement. They do not find them to be unethical or unacceptable as the previous two groups and feel that they actually enhance the aesthetic realism of the content. Audience is disinclined to have the 
government regulate brand placement regardless of medium.

Williams et al (2011) suggest that movies and programmes are watched many times; accordingly, product placement is not limited in time to the original filmed item. In addition, today's technology can insert product placement in places they were not before. This digital product integration is a new frontier for paid product placement. As a result, consumers will see more and more product placements that are strategically placed in the media. In Kozak's research (2011), output is a new marketing rule: "Find out, what the customers want, and then bring it to the market" was newly transformed to "Invite your customers to process of developing new product, use their enthusiasm and bring to the market a new product outgoing from their ideas. These customers make word of mouth marketing of this product for free".

According to Asamoah and Chovancová (2011), brand and its perceived value and position in a competitive field (a price reduction of strong brands is perceived as suspicious; with the strong media supported brand advertising, a buyer may be willing to pay any price, regardless of price endings). It is recommended that managers integrate a psychological pricing concept into their pricing strategies, particularly because of the predominance of price endings for fast moving goods.

\section{Problem Formulation}

The present study aims to investigate the products promoted using product placement from the point of view of producers of audiovisual works, representatives of television companies and specialists. It also attempts to analyze and identify the questions of ethics among audience, producers, broadcasters and television advertisers. Emphasis is placed on the issues related to the correct targeting of such activities, which is closely related to product placement. Finally, based on an analysis of the data collected, the study shows the current situation, the level of knowledge and the opinion of marketing specialists on the types and forms of embedded marketing.

\section{Methods Used}

Due to the narrowness of Czech market, a structured interview with the experts in film, series, sitcom and television program making has been chosen as the most suitable tool for the investigation of these issues. In the first phase of research done in the first half of year 2011, a method of fully-structured interview was used. It was designed by the authors of the paper based on the experience from their previous research. The inquiry covered all principal television organizations in the Czech Republic (TV NOVA, PRIMA and Czech Television). Television advertising experts as well as experts from the Committee for Radio and Television Broadcasting were addressed. The primary aim was to investigate what forms of product placement are known by producers and television studios. This was done by means of guided interview, during which the individual main points of the questions were noted in questionnaires and, at the same time, recorded on the voice recorder for the purpose of a subsequent transcription of full answers that were entered into the database of results.

In the second phase of the research, the results were analyzed using quantification and by means of seeking a mutual dependence. Structured interviews contained 12 open questions. The experts were divided into several categories with common features. In total, 24 interviewees from television organizations and other experts took part in the research. The results obtained were subject to a statistical study.

\section{Problem Solution}

The current state of the use of product placement and the knowledge of this marketing tool in subjects examined on the Czech market are characterized by the 
following queries. In the case of a majority consensus, the data are quantified by a relative indicator and supplemented by important findings in the form of a comment. In the case of fragmentation of answers, only the most important findings in the surveyed area are listed.

What types and forms of product placement do you know?
This open question focused on what types of product placement and especially how many of them the respondent was able to recall. It should be noted that the researchers have no information about the literature or other sources from which the respondent learnt about the instrument above. The research shows that respondents mentioned only five forms of product placement, from either audiovisual or marketing perspective.

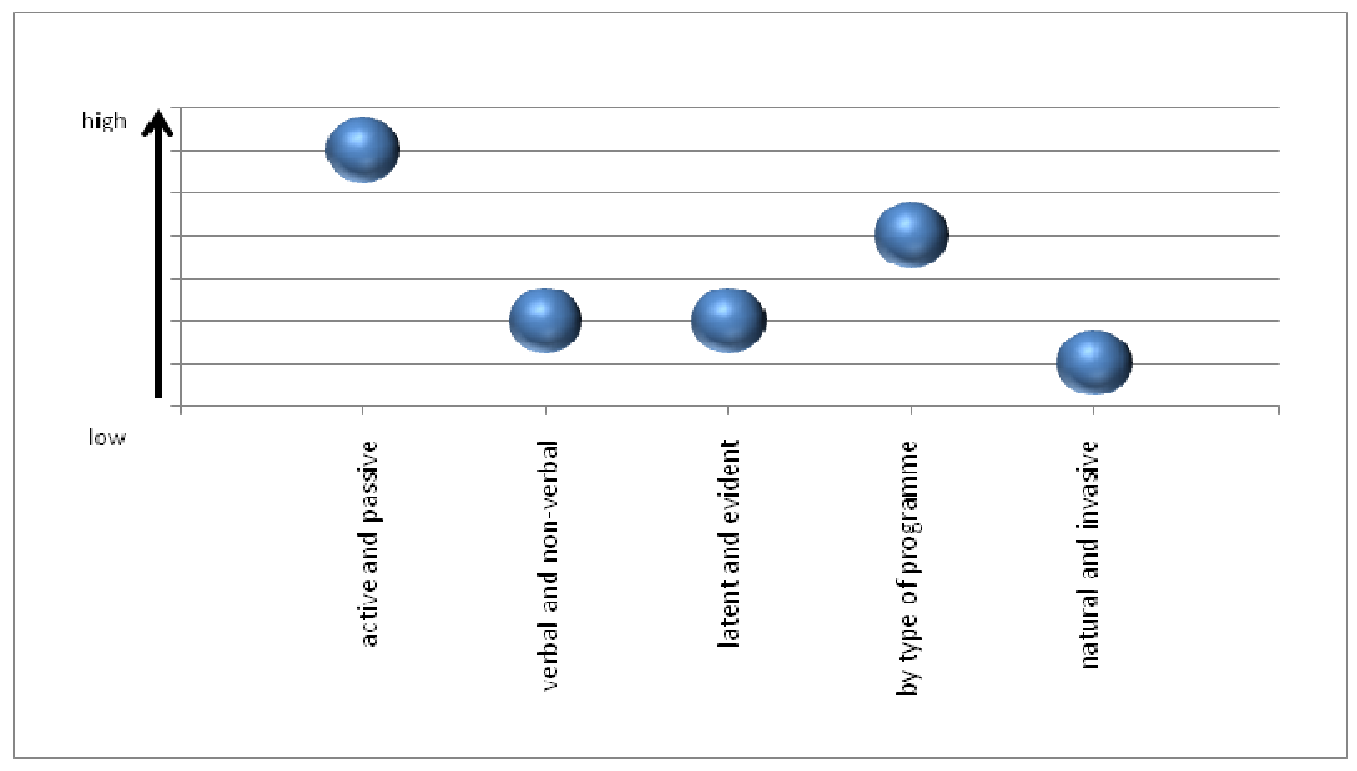

Fig 1. Awareness of Types and Forms of Product Placement

The most commonly found form of product placement was active and passive (awareness of 60\%) which can be interpreted as follows: a product is embedded into a work so that it is either clearly visible, or it is also verbally mentioned or used in a film script - it plays its own role.

The second most frequently mentioned form of product placement was according to the type of programme (the second highest awareness). This can be caused by the fact that placement of the product depends on thematic type of a programme, i.e. it is inevitable for the product to perfectly suit into the content of an audiovisual work.
Verbal/non-verbal reference and latent/evident placement are found on the third place, both with nearly the same level of awareness.

The least known (awareness of $10 \%$ ) type of product placement is natural (organically integrated) and unnatural product placement. This type is also referred to as invasive/non-invasive. Invasive product placement can be understood in a way that the product is embedded into the story artificially and disturbs the scenario.

What products are most often promoted by product placement? 
What products are most often promoted by product placement? The results imply that the tool is most commonly used for promotion of automotive industry (40\%), followed by a group of products called "Others" (the group covers especially financial institutions and electrical appliances including mobile phones). Daily consumption products occupy the third position and $15 \%$ are made up of alcohol and soft drinks.

As the sale price of automobiles is still high, the automotive industry also continues to exploit classic ATL (above the line) marketing tools, especially a full-page advertisement in magazines, outdoor advertising, TV commercials and other expensive marketing tools which address the masses.

A survey on product promotion using product placement was published also by Media Master (C2009). The company offers services related to sale of advertising space and other marketing services. According to the survey, the following product categories are mostly promoted by product placement (ordered by importance):

1. Automobiles

2. Mobile phones and computers

3. Foodstuff

4. Beverages

5. Travel agencies

6. Resorts

7. Services

8. Transport companies

The following table gives an overview of the market situation in the Czech Republic.

Table 2: Overview of the Market Situation in the Czech Republic

\begin{tabular}{|l|l|l|l|}
\hline Product category & $\begin{array}{l}\text { Finding in our } \\
\text { research }\end{array}$ & $\begin{array}{l}\text { Finding in the } \\
\text { survey of Media } \\
\text { Master }\end{array}$ & Match \\
\hline Automobiles & $\mathrm{x}$ & $\mathrm{x}$ & $\mathrm{x}$ \\
\hline Consumer electronics & $\mathrm{x}$ & $\mathrm{x}$ & $\mathrm{x}$ \\
\hline Mobile phones and computers & $\mathrm{x}$ & $\mathrm{x}$ & $\mathrm{x}$ \\
\hline Food and beverages & $\mathrm{x}$ & $\mathrm{x}$ & $\mathrm{x}$ \\
\hline Travel agencies and resorts & & $\mathrm{x}$ & \\
\hline Other services & & $\mathrm{x}$ & \\
\hline Transport services & & $\mathrm{x}$ & \\
\hline Financial institutions & $\mathrm{x}$ & \\
\hline Daily consumption products & $\mathrm{x}$ & & $44 \%$ \\
\hline Overall match & & & \\
\hline
\end{tabular}

When comparing the results of the present research with the results of Media Master survey, there is resemblance especially in categories of automobiles, mobile phones and computers and food and beverages. No finding in categories of travel agencies and resorts and transport services occurred in the present research. Overall match was quantified as four out of nine categories, i.e. $44 \%$.

A similar survey was performed by La Ferle and Edwards (2006) from Michigan State University as well. They have discovered the following order of products promoted using product placement: 
1. Other services
a. Media and entertainment (32.7\%)
b. Service companies ( $8.8 \%)$
c. Organizations $(8.5 \%)$
d. Personal care items (1.4\%)
e. Miscellaneous (1.4\%)
f. Airlines (1.3\%)

2. Daily consumption products
a. Sports-related products (7.2\%)
b. Stores $(3.0 \%)$
c. Health-care products $(2.7 \%)$
d. Household products (1.5\%)

3. Food and beverages (9.3\%)
4. Automobiles (7.1\%)

5. Mobile phones and computers (4.2\%)

6. Financial institutions (2.1\%)

7. Travel agencies, resorts and restaurants (1.9\%)

In a research study by LaFerle and Edwards (2006) of the 1992 brand placements, most were rated as neutral (90.8\%), potentially indicating the lack of control that most companies have in placing their products at this point in time.

According to Chráska (2007), in order to find out how tightly are connected these rankings (two pairs each time) detected by ordinal measure, the researchers used Spearman's rank correlation coefficient. Using this coefficient, the researchers investigated how similar two rankings are. The following table is the outcome.

Table 3: Ranks of Product Category

\begin{tabular}{|l|l|l|l|}
\hline Product category & Rank in the research & $\begin{array}{l}\text { Rank in the survey of } \\
\text { Media Master }\end{array}$ & $\begin{array}{l}\text { Rank in the survey } \\
\text { by La Ferle, } \\
\text { Edwards }\end{array}$ \\
\hline Automobiles & 1 & 1 & 4 \\
\hline $\begin{array}{l}\text { Daily consumption } \\
\text { products }\end{array}$ & 2 & 8 & 2 \\
\hline Food and beverages & 3 & 3 & 3 \\
\hline $\begin{array}{l}\text { Mobile phones and } \\
\text { computers }\end{array}$ & 4 & 2 & 5 \\
\hline Consumer electronics & 5 & 8 & 8,5 \\
\hline Financial institutions & 6 & 8 & 6 \\
\hline $\begin{array}{l}\text { Travel agencies and } \\
\text { resorts }\end{array}$ & 8 & 4 & 7 \\
\hline Other services & 8 & 5 & 1 \\
\hline Transport services & 8 & 6 & 8,5 \\
\hline
\end{tabular}

Calculation of Spearman's rank correlation coefficient was performed using the following formula. (Chráska, 2007)

$r_{s}=1-\frac{6 \times \sum d^{2}}{n\left(n^{2}-1\right)}$
Spearman's rank correlation coefficient between the hereby research and Media Master survey is 0.3167. Comparing the results of the present research with La Ferle and Edwards survey, the coefficient is 0.3958. Coefficient between Media Master 
survey and survey of La Ferle and Edwards is 0.2542 . These values imply that there exists a rather low positive dependence among the rankings.

From Table 3, one can see that automobiles are ranked in the first place in the Czech market in both surveys. The researchers can also compare the order of product categories between the markets in the Czech Republic and the USA. There are only minimal differences in rankings among daily consumption products, food and beverages as well as mobile phones and computers.

How do you view the ethical dimension of product placement?

The above question investigated the opinions of audiovisual works experts, producers and traders from TV stations in the Czech Republic. The results are clear -the vast majority of 24 answers assess the ethical dimension of product placement positively. Brief summary of the prevailing opinion could be: "product placement is just another type of marketing tool, having been used already before getting this exact name and its usage in audiovisual works is not unethical". However, the answers also indicated that this tool should not be used too invasively and artificially, as this could cause disruption of scenario and would lead to a dramatic weakening of cultural and entertaining component of audiovisual work.

It must be also mentioned that $4.2 \%$ of respondents strongly disagree with using this marketing technique. They find it a tool which deceives the viewer and destroys traditional construction of film script and production of audiovisual work. According to this segment of respondents, the use of embedded marketing is unethical in principle.

\section{Conclusion and Discussion}

The three areas investigated in this paper (types and forms of product placement utilization, type of promoted product and ethical dimension) have a significant impact on the efficiency of product placement. The following Fig. 2 also confirms this statement.

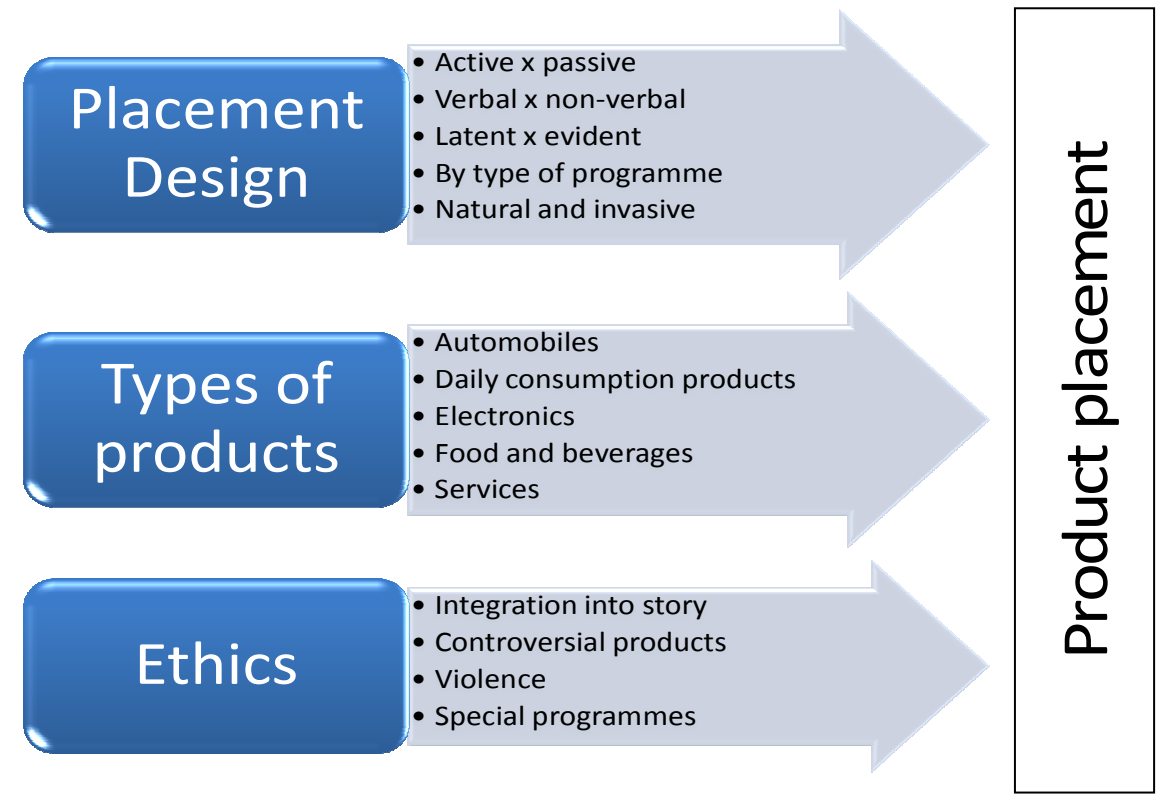

Fig 2. Impact on the Efficiency of Product Placement 
Product placement as a form of modern marketing is not suitable for all products. It is obvious that product placement is appropriate especially for B2C marketing and for products where we intend to build a prime brand. According to the above surveys, these products are especially automobiles, consumer electronics such as laptops and telephones, as well as alcoholic beverages. The aim of product placement is not to persuade the viewer to buy the product directly. Instead, product placement is about building associations. Viewers prefer having products in the story than being broken away for 30-second commercial spots.

According to Lindström (2009), Williams et al (2011) and Zebrowski and MacDonald (2007), it is the association, or link-up of a product or a brand seen in an audiovisual work that is a subject of a problematic area of ethics. When is this form of promotion ethical and when it is not? Specialists find this tool positive and claim that when following logical rules of common sense, being in line with the work's scenario and placing the products sensitively, everything is ethical. If product placement fits in the story, viewers do not feel bothered. And regarding the question of ethics - the researchers believe that product placement can be a negative force and can go too far but in most cases it benefits everyone getting paid for content. However, situation is different in case of the so-called ethically controversial products such as alcohol, cigarettes, guns (Williams et al, 2011) and so on, as well as in case a movie contains too much violence (Hudson and Hudson, 2006). In a research study by Williams et al (2011) another category cited is news and programmes for children. Here is important the influence of gender division of viewers and their personal opinion on the type of product and amount of violence.

Dispute arises when marketing messages are not integrated organically and when the storyboard is significantly of artificially disturbed. Audience cannot distinguish where the product is placed with promotion intent, unlike traditional commercial breaks which they can ignore - the so-called "ad blindness". On the other hand, Williams et al (2011) and Lindström (2009) claim that if product placement does not fit in the story, it is ineffective and companies' investment goes in vain.

Nowadays, product placement is a win-win situation for everyone. It increases revenues of broadcasters and allows them to cut risk, while, as for the advertisers it increases their chance of viewership and brand recall. Moreover, viewers get informed about the products.

\section{Acknowledgment}

This work was supported by IGA (Internal Grant Agency - Faculty of Economics and Management) Project Nr. IGA/53/FaME/11A.

\section{References}

Asamoah, E. S. \& Chovancová, M. (2011). "The Influence of Price Endings on Consumer Behavior: An Application of the Psychology of Perception," Acta Universitatis Agriculturae et Silviculturae Mendeleianae Brunensis, 59 (7), 29-38.

Balfanz, D., Finke, M., Jung, C. \& Wichert, R. (2001). "An Interactive Video System Supporting E-Commere Product Placement," Proceedings of the Wseas International Conferences Ssip'01, Malta. [Online]. Available: www.wseas.us/elibrary/conferences/malta2001/papers/255 .pdf.

Chen, F.- P. \& Leu, J.- D. (2011). "Product Involvement in the Link between Skepticism toward Advertising and Its Effects," Social Behavior and Personality, 39 (2), 153-160.

Chráska, M. (2007). Metody Pedagogického Výzkumu: Základy Kvantitativního Výzkumu. Prague: Grada.

Guido, G., Peluso, A. M., Tedeschi, P., Nicole, C., Lauretti, C. \& Caciula, A. (2010). "Acceptance of Product Placement in Italy: 
11 Journal of Eastern Europe Research in Business \& Economics

Effects of Personality and Product/Consumer Interactions," International Journal of Marketing Studies, Toronto: November, 2 (2), 34.

Hudson, S. \& Hudson, D. (2006). "Branded Entertainment: A New Advertising Technique or Product Placement in Disguise?," Journal of Marketing Management, 22 (5/6), 489504.

Kozák, V. (2011). 'Marketing Communication Selected Brewing Companies in the Czech Republic in Traditional and New Marketing Communication,' Zlín, Verbum, Pp. 91 - 98.

Kureshi, S. \& Sood, V. (2010). "A Review of Placement Literature: Conceptual and Managerial Implications," Iup Journal of Marketing Management, 9 (1/2), 23-39.

La Ferle, C. \& Edwards, S. M. (2006). "Product Placement: How Brands Appear on Television," Journal of Advertising, 35 (4), 6586.

Lehu, J.- M. (2007). Branded Entertainment: Product Placement \& Brand Strategy in the Entertainment Business. London: Kogan Page.

Lexus. (2010). "What Is Embedded Marketing," Bukisa: Share Your Knowledge [Online]. Nov 15th [Retrieved 2012-02-09]. Available:

http://www.bukisa.com/articles/396555_w hat-is-embedded-marketing.

Lindström, M. (2009). 'Nákupologie: Pravda A Lži O Tom, Proč Nakupujeme,' Brno: Computer Press.
Media Master. (2009). 'About us' [Online]. [Retrieved 2012-02-27]. Available: http://www.media-master.cz/.

Pálková, M. (2010). 'Product Placement: Basic Characteris and Main Rules for Using in Czech TV and TV Barrandov,' MediaMaster [Online]. 1.6.2010 [Retrieved 2012-02-27]. Available:

http://www.mediamaster.cz/files/Martin/P P/Pravidla\%20pro\%20Product\%20Placeme nt_2010.pdf.

Powell, H., Hardy, J., Hawkin, S. \& Macrury, I. (2009). The Advertising Handbook. 3rd Edition. London: Routledge.

Přikrylová, J. \& Jahodová, H. (2010). Moderní Marketingová Komunikace. Prague: Grada. 'Shopper Watch'. (2011). Checkout, 37 (6), 69-71.

Vysekalová, J. \& Mikeš, J. (2010). 'Reklama: Jak Dělat Reklamu,' 3rd Edition. Prague: Grada.

Williams, K., Petrosky, A., Hernandez, E. \& Page, R. (2011). "Product Placement Effectiveness: Revisited and Renewed," Journal of Management \& Marketing Research, 7, 1-24.

Zebrowski, K. \& Macdonald, J. (2007). 'Product Placement: An Ethical Question,' Slideshare [Online]. Apr 08 [Retrieved 201202-09]. Available: http://www.bukisa.com/articles/396555_w hat-is-embedded-marketing. 